\title{
Principales dilemas bioéticos en las personas con discapacidad prolongada
}

Rueda C. Laura, Miranda Z. Orquidea

\begin{abstract}
Resumen
Reconocida es a nivel mundial la dificultad para alcanzar la plena participación e integración social de las personas con discapacidad, situación que involucra valores éticos fundamentales. Un aporte importante será la aplicación de principios bioéticos orientadores del quehacer profesional bajo un nuevo paradigma. Dilemas bioéticos como el consentimiento informado y la participación de la persona en la toma de decisiones que afectan su propia vida, implican para el profesional un desafío, la entrega de información adecuada y oportuna, el desarrollo de conductas profesionales que favorezcan la autonomía y el reconocimiento de estas personas como interlocutores validos. Del mismo modo ocurre cuando abordamos la sexualidad de las personas con discapacidad. Los profesionales deben permitir el desarrollo integral de las personas, reconociendo la sexualidad como un aspecto fundamental del ser humano, y frente al cual tienen derecho a ser orientados y educados tomando como base su historia biográfica y lo que cada uno desea de la vida (autodeterminación). Deben ser considerados por tanto, principios bioéticos fundamentales como la Justicia y la autonomía.
\end{abstract}

\begin{abstract}
- Abstract
Recognized it is at world level the difficulty to reach the full participation and people's social integration with handicap, situation that involves fundamental ethical values. An important contribution will be the application of bioethics principles direction of the professional chore under a new paradigm. Bioethics dilemmas like the informed consent and the person's participation in the taking of decisions that affect their own life, imply for the professional a challenge, the delivery of appropriate and opportune information, the development of professional behaviors that the autonomy and the recognition of these people like valid speakers favor. When speaking of sexuality, the professionals should allow the integral development of people, recognizing the sexuality like the human being's fundamental aspect, and in front of which you/they are entitled to be guided and educated taking like base their biographical history and what each one wants of the life (self-determination). They should be considered therefore, bioethics principles fundamental as the Justice and the Autonomy.
\end{abstract}

